\title{
The Shackles of History: The Hidden Protagonist of Homegoing
}

\author{
Stella P. Maymin \\ Student, Rye Country Day School, USA
}

Received: 07 Dec 2021; Received in revised form: 14 Jan 2022; Accepted: 25 Jan 2022; Available online: 07 Feb 2022 C2022 The Author(s). Published by Infogain Publication. This is an open access article under the CC BY license (https://creativecommons.org/licenses/by/4.0/).

\begin{abstract}
In Yaa Gyasi's Homegoing, history possesses more agency over the future trajectory of societal and individual lives than any character does. In examination of H, Akua, and Marcus, the control of history is apparent on their backgrounds and their futures.

Keywords-protagonist, history, freedom, agency, Homegoing.
\end{abstract}

\begin{abstract}
I.
\section{INTRODUCTION}

They would just trade one type of shackles for another, trade physical ones that wrapped around wrists and ankles for the invisible ones that wrapped around the mind" (Gyasi, 93). Once people are torn from their homes and families, shipped across the ocean, and treated worse than cattle, they remain scarred, both figuratively and literally. Homegoing is a family saga novel, following the generations of two half-sisters as they live through the height and slight decline of slave trading. It speaks to the metaphoric and literal scarring of enslaved individuals during this time. H spent decades in "physical" shackles as he was part of the Convict Leasing Program, a sect of slavery that "legally" shoved him into coal mines for a large portion of his life. Akua was raised with "invisible" shackles in Missionary School after her mother drowned while she was young. Marcus was born in a more modern part of history without shackles completely, and he constantly tortures himself with questions about his luck of not being enslaved or imprisoned merely because of the time period he was born into. Through $\mathrm{H}$, Akua, and Marcus, specifically, and the rest of the novel, history has more agency than any individual character. The characters' attempts to change their lives seem futile as they are not able to alter what society has projected onto them, and their lives remain relatively the same from parent to child to grandchild and so forth. History itself is the protagonist in Homegoing, possessing more agency over the future than any individual character.
\end{abstract}

\section{METHOD}

The method used to analyze Homegoing focuses on the historical sense of control that is given up by the individuals. By connecting multiple characters' experiences, their lack of agency is highlighted through Yaa Gyasi’s interpretation of history.

The overlapping and overarching power of history throughout the family saga novel is seen on every character, although few attempt to better their lives against the trajectory of their community, society, and/or backgrounds.

According to Seligman (2021), agency comprises "efficacy, future-minded optimism, and imagination." Throughout this piece, we will explore these concepts as they apply to various candidate protagonists.

\section{RESULTS AND DISCUSSION}

$\mathrm{H}$ lacks a connection with his name, and thus initially misunderstands Ethe's deep connection with her own which leads to history keeping them apart for decades. $\mathrm{H}$ was traumatized as part of a ripple of slavery after it had been legally abolished. He lived most of his life as a "convict" in the Convict Leasing Program, a strategic program that treated unfairly convicted felons as slaves and filtered some profits to the government. H spent decades underground, mining coal against his will. His father searched endlessly for his wife after she had been abducted and sold into slavery, but he could not find her or their son. His pregnant mother had attempted to commit suicide to escape a life in slavery for her and her son; and although she died, her son survived. Slaves often had a 
deep connection to their names, as it remained a portion of their identity that could not be stolen, altered, or ruined. However, $\mathrm{H}$ was unable to experience this attachment, as his mother refused to give him a name prior to committing suicide. In her mind, giving him a name would jumpstart her baby's life as a slave and give their master a name to scream in between whips. So $\mathrm{H}$ remains with the placeholder for his name, as unbeknownst to him, his siblings were named in alphabetical order and next in line was "H." He should have understood how his girlfriend, Ethe, was so drawn to the name her mother had given her because of his own longing for a name he could love as much as the idea of his family. After his release from the Convict Leasing Program, $\mathrm{H}$ went to make amends with Ethe for calling her by the wrong name, and she was rightfully upset: “'Ain't just about everything been taken from me? My freedom. My family. My body. And now I can't even own my name?"' (Gyasi, 175). This quotation speaks to the importance of names and how it relates strongly to identity, especially for enslaved and previously enslaved people. Ethe continues to explain that she only had "six good years with her [mother]" and now, her name was the only memorabilia she had left of her (Gyasi, 175). Ethe asks $\mathrm{H}$, rhetorically, if she had already survived through enough torture, as the only piece of herself truly attached to her identity, her family, and herself had been recently neglected by the one person left that she had fully trusted because he was cheating on her. Ethe speaks to the time that she had served as a slave, and how it had stolen her "freedom," her "family," and her "body," and left her without a voice, an opinion, and any agency in her own life (Gyasi, 175). Ethe and $\mathrm{H}$ had different relationships with their names, but both reflect their lack of efficacy over their lives, which are instead influenced by outside forces and society. Even though $\mathrm{H}$ was able to reach out and make amends with Ethe after years of regret, she had spent most of that time thinking of and looking for him. $\mathrm{H}$ and Ethe were able to better their lives in minute ways, however the majority of their lives were regulated and controlled by the trajectory of history and their society. The proceedings of history indirectly ended the life of H's mother, resulting in $\mathrm{H}$ and Ethe having issues in their relationship which kept them apart for decades.

Akua was so traumatized by her family and history that she was pushed to murder her daughters in a fire resulting in her nickname "Crazy Woman" for the majority of her life. Similar to H, Akua was born into an environment of suffering with poor mental health due to the effect of history on her ancestors. Her mother, Abena, was murdered in a lake and left Akua to be raised in the Missionary Church by the racist Missionary. Akua later viewed the burning of an innocent, white man, and she was one of few to understand his final pleas of innocence, as she silently stood by and watched his death with the rest of the crowd. Akua fights against this figure of her nightmares as it morphs into a woman in a cloak of fire searching for her children, for months. She eventually sentences her own children to the same death that traumatized her for years because of her difficulty to cope with her own history. When Akua is tied to a tree and sentenced to the same death the white man had been, she is unaware of what she had done. Once the villagers begin to question why her husband begs to keep her alive after she had killed his children, she was in a state of shock: "The woman who killed her children? She was asleep. She must still be asleep" (Gyasi, 198). Her internal questioning of what the villagers are telling her she had done shows her true incompetence as a member of their society. She is so troubled by her visions of the firewoman that she can not control nor even remember her actions. In Akua's final dream of the firewoman, the firewoman had finally found her children and Akua held them. Even though Akua's hands became covered in flames, she "played with the braided ropes of fire that made up their hair, their coalblack lips" (Gyasi, 197). This vision of fire-charred children took up Akua's headspace and resulted in her sentencing her own daughters to this final torture. It is as if once Akua "gave" her children to the "fire," the firewoman is now able to find and hold Akua's children, and Akua is able to say goodbye to them. Akua seems to envision her children in the blanket of fire she has unknowingly placed them in as fire spread over their "braided" locks and their lips morph from soft pink to "coal-black." Gyasi's word choice emphasizes how detailed Akua's fear and visions of the firewoman were, and how tortured Akua was by the sight of children on fire. It seems that the weight of her ancestor's lives were metaphorically on her shoulders, and the weight finally caused her to break. The early years of Akua's life tormented her for the rest of her days, as history tortured her with the loss of her mother, the racism of her Missionary, and spectating the death of an innocent man. Because of Akua's incapacity to deal with such trauma in her early life due to a lack of future-minded optimism, her suffering spilled out in the form of nightmares and a murder by fire.

Marcus is deeply perplexed that he was not enslaved as his ancestors were due only to the time period he was born in. Because of his disbelief, he spends most of his life researching the history of slavetrade and teaching history courses to children to avoid slavery ever returning to his society. It was very difficult to keep track of family trees and heritage during slavery and the slave trade, which resulted in Marcus' mixed feelings about not fully understanding his background. He struggled with the 
disbelief that he was not a slave as his ancestors were, purely due to his luck of being born in a later time period. This emphasizes how history altered Marcus' life, not the actions of his ancestors or himself, but merely the passing of time and the progression of society. Throughout Marcus' life he questioned, researched, and studied "the fact that he had been born, that he was not in a jail cell somewhere, [and how it] was not by the dint of pulling himself up by the bootstraps, not by hard work or belief in the American Dream, but by mere chance" (Gyasi, 296). Gyasi's word choice of "mere chance" shows that Marcus understands that his state of freedom is not because of "hard work" on the part of his ancestors nor his early childhood. Often, as he sits at the dinner table with his family, he begins to imagine in great detail other family members from years past. It seems unbelievable, as characters from earlier chapters are rehashed, that Marcus is able to so accurately guess who his ancestors were. However, perhaps growing up with his immediate family, learning about and teaching history to his students, and a deep understanding of the impacts and traumas of slave trading helped him to fill in the blanks.

\section{CONCLUSION}

In Homegoing by Yaa Gyasi, the characters are unable to alter the trajectory of society nor their lives, as they lack the agency that history maintains over them. Throughout the analysis of the individual characters, each chosen character in this piece lacks one of Seligman's three factors of agency, which further proves that history is the true protagonist of the novel. As, even though the characters attempt to better the lives of themselves, their children, and their grandchildren, they each eventually succumb to the societal expectations set for them, their ancestors, and their successors.

\section{REFERENCES}

[1] Gyasi, Yaa, Homegoing. New York: Alfred A. Knopf, 2016.

[2] Seligman, Martin (2021). "Agency in Greco-Roman

Philosophy.” The Journal of Positive Psychology 16, 1-10. 